\title{
Proteasome (prosome) subunit variations during the differentiation of myeloid U937 cells
}

\author{
Laurent Henry ${ }^{\mathrm{a}}$, Ahsene Baz ${ }^{\mathrm{a}}$, Marie-Thérèse Château ${ }^{\mathrm{a}}$, René Caravano ${ }^{\mathrm{a}}$, \\ Klaus Scherrer ${ }^{\mathrm{b}}$ and Jean Paul Bureau ${ }^{\mathrm{a}, *}$ \\ ${ }^{a}$ Laboratoire de Biologie Cellulaire et Cytogénétique Moléculaire (UPRES-JE 1952), \\ Faculté de Médecine de Montpellier-Nîmes, Université Montpellier I, Nîmes, France \\ ${ }^{\mathrm{b}}$ Institut Jacques Monod, CNRS et Université Paris VII, Paris, France
}

Received 12 May 1997

Revised 3 July 1997

Accepted 7 October 1997

\begin{abstract}
S proteasomes (prosomes/multicatalytic proteinase) are protein particles built of 28 subunits in variable composition. We studied the changes in proteasome subunit composition during the differentiation of U937 cells induced by phorbol-myristate-acetate or retinoic acid plus 1,25-dihydroxy-cholecalciferol by western blot, flow cytometry and immunofluorescence. p25K (C3), p27K (IOTA) and p30/33K (C2) subunits were detected in both the nucleus and cytoplasm of undifferentiated cells. Flow cytometry demonstrated a biphasic decrease in proteasome subunits detection during differentiation induced by RA+VD. PMA caused an early transient decrease in these subunits followed by a return to their control level, except for $\mathrm{p} 30 / 33 \mathrm{~K}$, which remained low. Immuno-fluorescence also showed differences in the cytolocalization of the subunits, with a particular decrease in antigen labeling in the nucleus of RA+VD-induced cells, and a scattering in the cytoplasm and a reorganization in the nucleus of PMA-induced cells. Small amounts of proteasomal proteins were seen on the outer membrane of non-induced cells; these membrane proteins disappeared when treated with RA+VD, whereas some increased on PMA-induced cells. The differential changes in the distribution and type of proteasomes in RA+VD and PMA-induced cells indicate that, possibly, 20S proteasomes may play a role in relation to the mechanisms of differentiation and the inducer used.
\end{abstract}

Keywords: Proteasome (prosome, multicatalytic proteinase), differentiation, myeloid, leukemic, cytolocalization, western blot, flow cytometry, immunofluorescence

\section{Abbreviations}

RA, all-trans-retinoic acid;

VD, 1,25-dihydroxy-cholecalciferol = vitamine D3;

PMA, phorbol 12-myristate 13-acetate;

$\mathrm{p}-\mathrm{mAb}$, anti-proteasome monoclonal antibody;

MFI, mean fluorescence intensity;

SEM, standard error of the mean.

${ }^{*}$ Corresponding author: Prof. Jean Paul Bureau, Laboratoire de Biologie Cellulaire et Cytogénétique Moléculaire (UPRESJE 1952), Faculté de Médecine, Université Montpellier I, Avenue Kennedy, 30900 Nîmes, France. Tel.: +1 334662328 06; Fax: +1 334662307 19; E-mail: bureau@zeus.sc.univ-montp1.fr. 


\section{Introduction}

$20 \mathrm{~S}$ proteasomes (prosomes, multicatalytic proteinase complexes) $[3,43,49]$ are very stable high molecular mass $(720 \mathrm{kDa})$ complexes. They are $15 \mathrm{~nm}$ long cylindrical particles of $11 \mathrm{~nm}$ diameter that contain 14 distinct proteins, with molecular mass ranging from 20 to $38 \mathrm{kDa}$, organized in four stacked rings of seven subunits [16,25]. They constitute the core of the $26 \mathrm{~S}$ complex [15] and are found in archaebacteria, eubacteria and all eukaryotic cells, from yeast to human, and in plants [12]. Their best characterized function is multi-catalytic proteinase activity inside the $26 \mathrm{~S}$ complex, they are implicated in numerous functions including antigen presentation [6,32], regulation of cell cycle $[20,41]$, transcription $[34,35]$ and apoptosis [13]. Recently, they were shown to contain RNAse activity $[38,40]$. For review, see [11,42].

Individual proteasomes are "mosaics" of subunits. The presence and distribution of proteasomes within the cell compartments appears to vary according to the proteasomal protein probed. The specific subunit patterns vary as a function of species, cell type, state of differentiation and pathology [1,5, $7,8,14,17-19,36,44,48]$. Proteasomes may reflect or be involved in differential gene expression and thus in cell differentiation and/or in the establishment of the morphological and functional parameters of differentiated cells.

The present study examines the changes in $20 \mathrm{~S}$ proteasome content, composition and location during the differentiation of U937, a human monoblast-like histiocytic leukemia cell line that can be induced to differentiate into a macrophage-like cell by incubation with PMA or RA+VD [31,45]. The differentiation of U937 along the monocytic-macrophage pathway provides a valuable model for studying the changes in proteasomes during cell differentiation and may shed light on their functions.

\section{Materials and methods}

\subsection{Cell culture}

U937 cells from ATCC (Rockville, MD, USA) were grown in RPMI 1640 medium supplemented with $2 \mathrm{mM} \mathrm{L}$-glutamine and $10 \%$ low-endotoxin, heat-inactivated $\left(30 \mathrm{~min}\right.$ at $\left.56^{\circ} \mathrm{C}\right)$ fetal calf serum (Sera-Lab, Crawley Down, Sussex, England) at $37^{\circ} \mathrm{C}$ in a humidified, $95 \%$ air and $5 \% \mathrm{CO}_{2}$ atmosphere. Cells were maintained as stationary cell suspension cultures at a maximum concentration of $10^{6}$ cells $/ \mathrm{ml}$ and passaged every two to three days. Viability of control cells was always more than $95 \%$, as estimated by Trypan blue exclusion. For differentiation, the cells were rinsed and cultured in presence of 160 nM PMA (Sigma, Saint Quentin Fallavier, France) [31], or 100 nM RA plus 100 nM VD [45].

\subsection{Antibodies}

Proteasomal proteins were labeled with ascitic mouse monoclonal antibodies (p-mAbs) directed against purified 20S proteasomes [17], distributed by Organon Teknika (Turnhout, Belgium): antip25K (7A11) recognize a protein of $25 \mathrm{kDa}$ which was identified (Hendil, personal communication) as the $\mathrm{C} 3$ alpha subunit, anti-p27K (IB5) react with a $27 \mathrm{kDa}$ protein identified as the IOTA alpha subunit and anti-p30/33K (62A32) recognize a $33 \mathrm{kDa}$ protein identified as the $\mathrm{C} 2$ alpha subunit. For review of known 20S proteasomal proteins, see Tanaka [47] and Kristensen et al. [26]. Irrelevant was included in each series using normal mouse immunoglobulins (Sigma, Saint Quentin Fallavier, France) in place to the monoclonal antibody. 


\subsection{Flow cytometry}

Fluorescence was analyzed by a flow cytometer (FACScan, Becton-Dickinson, Mountain View, CA, USA) equipped with an argon ion laser operating at $488 \mathrm{~nm}$ and $15 \mathrm{~mW}$. Data were recorded in the list mode via the LysisII program for immunophenotyping and the CellFit program for DNA content. The calibration of the photomultiplier tubes was checked with a suspension of standardized fluorescent beads (CaliBRITE, Becton-Dickinson). 10,000 cells were counted in each experiment. The green fluorescence of fluoro-isothyocyanate (FITC) was collected via a $518 \mathrm{~nm}$ filter and the red fluorescence of propidium iodide (PI) via a $577 \mathrm{~nm}$ filter. Gating on dot plot was used to distinguish cells from debris (forward versus side scattering) and for single cells analysis of DNA content (area versus peak of red fluorescence).

Single staining: $10^{6}$ cells were washed $(3 \times 5 \mathrm{~min})$, preincubated for $15 \mathrm{~min}$ with $5 \%$ normal goat serum (Sigma), washed again $(3 \times 5 \mathrm{~min})$ and incubated $30 \mathrm{~min}$ with the mouse p-mAbs diluted in PBS-1\% BSA. The cells were then washed $(2 \times 5 \mathrm{~min}+1 \times 15 \mathrm{~min})$ and incubated with FITC conjugated goat anti-mouse (GAM-FITC, Coulter, Hialeah, FL, USA) antibody in PBS-BSA, washed again $(2 \times 5 \mathrm{~min}+2 \times 15 \mathrm{~min})$ and suspended in PBS for analysis by flow cytometry. Intracellular antigens were examined on cell permeated by incubation for $30 \mathrm{~min}$ in cold $70 \%$ ethanol.

DNA content: The DNA content was measured by staining with intercalating agent propidium iodide (20 $\mu \mathrm{g} / \mathrm{ml}$, Sigma).

Double staining: For staining of antigens and DNA simultaneously, cells were permeated, treated for indirect immunofluorescence and then incubated with propidium iodide.

\subsection{Immunofluorescence}

Cells were washed, centrifuged on a cytospin and fixed for $10 \mathrm{~min}$ in cold $70 \%$ ethanol. They were then rapidly rinsed, permeated by incubation for $15 \mathrm{~min}$ in $0.5 \%$ Tween-20 in PBS, rinsed for $10 \mathrm{~min}$ and preincubated for 15 min with normal goat serum diluted $1 / 20$ in PBS-BSA. The cells were washed again and incubated for $2 \mathrm{~h}$ with the primary antibody diluted 1/20 in PBS-BSA, washed for $30 \mathrm{~min}$ and incubated for $1 \mathrm{~h}$ with the fluorochrome-conjugated secondary antibody diluted $1 / 100$ in PBS-BSA. Finally, the cells were thoroughly washed and mounted in anti-fading medium (Oncor, Gaithersburg, MD, USA) for fluorescence microscopy.

\subsection{Western blotting}

Cells were suspended in buffer (Tris $\mathrm{HCl} 20 \mathrm{mM}$ pH 8.8, $\mathrm{CaCl}_{2} 2 \mathrm{mM}$ ) containing $0.3 \%$ SDS and $1 \%$ mercapto-ethanol and boiled for $2 \mathrm{~min}$. They were cooled in ice and treated by DNAse. An equal volume of $2 \times$ Laemmli-loading buffer was then added to the total protein extract. The proteins extracted from 250,000 cells were separated by SDS-PAGE and transferred to nitrocellulose membrane. The membrane was incubated with 5\% milk in PBS for 30 min to block non-specific adsorption sites and then overnight with the monoclonal antibody diluted 1:1000 in PBS containing $5 \%$ milk and $1 \%$ Tween-20. The membrane was washed for 30 min with $1 \%$ Tween-20 in PBS and incubated for $1 \mathrm{~h}$ with the goat anti mouse peroxidase-conjugated antibody diluted $1: 1000$ in PBS containing 1\% Tween-20. Lastly, the membrane was washed for 30 min with PBS containing $0.05 \%$ Tween-20, rinsed with water and incubated with the peroxidase substrate (DAB tablets, Sigma). 


\subsection{Preparation of nuclear and post-mitochondrial fractions}

The cells were pelleted and rinsed three times in NKM buffer (Hepes $10 \mathrm{mM} \mathrm{pH} \mathrm{7.4,} \mathrm{NaCl} 140 \mathrm{mM}$, $\mathrm{KCl} 5 \mathrm{mM}, \mathrm{MgCl}_{2} 1.5 \mathrm{mM}$ ). They were lysed in hypotonic TEKM-2 buffer (Tris $10 \mathrm{mM} \mathrm{pH} 7.4, \mathrm{KCl}$ $10 \mathrm{mM}, \mathrm{MgCl}_{2} 1 \mathrm{mM}, \mathrm{MnCl}_{2} 1 \mathrm{mM}$ ) containing $0.1 \%$ Nonidet-P40. The pellet volume was estimated, 4 volumes TEKM 2/0.1\% NP40 were added and the suspension was mixed for 5 min with a Pasteur pipet. Cell lysis was checked by microscopy and isotony was restored by sucrose $2 \mathrm{M}$ in TEKM-2 (1/7 total volume). The suspension was centrifuged at $2500 \mathrm{rpm}$ for $20 \mathrm{~min}$ at $4{ }^{\circ} \mathrm{C}$ and the pellet (nuclear pellet) was stored frozen at $-20^{\circ} \mathrm{C}$. The post-nuclear supernatant was once more centrifuged at $12,000 \mathrm{rpm}$ for $20 \mathrm{~min}$ at $4^{\circ} \mathrm{C}$, the resulting supernatant (post-mitochondrial supernatant) was stored frozen.

\subsection{Purification of proteasomes by immunoaffinity}

Proteasomes were purified on a Hi-Trap NHS-activated column (Pharmacia Biotech, Uppsala, Sweden) coupled to a polyclonal antibody prepared in the laboratory. The samples were centrifuged at $11,000 \mathrm{rpm}$ for $10 \mathrm{~min}$ at $4^{\circ} \mathrm{C}$, diluted $1 / 2$ in NET-2 $2 \times$ buffer (Tris $50 \mathrm{mM} \mathrm{pH} \mathrm{7.4,} \mathrm{NaCl} 150 \mathrm{mM}$, NP40 0.05\%) and charged on rinsed, prepared column. Unbound proteins were washed out with NET-2 buffer, aspecifically-bound non-proteasomal proteins were removed by washing with $0.1 \%$ Sarkosyl in NET-2. Proteasomal proteins were eluted by Glycine/ $\mathrm{HCl} 100 \mathrm{mM} \mathrm{pH} 3$. The $\mathrm{pH}$ was immediately raised with Tris- $\mathrm{HCl} 1 \mathrm{M}$ pH 8 buffer and proteins were precipitated with $10 \%$ trichloracetic acid, rinsed in acetone and frozen or suspended in loading buffer.

\section{Results}

\subsection{Cell differentiation}

The differentiation of U937 leukemic cells induced by $160 \mathrm{nM}$ PMA or $100 \mathrm{nM}$ RA plus $100 \mathrm{nM}$ VD was followed by monitoring morphological and functional parameters. RA+VD and PMA induced cells developed the typical morphology of differentiated cells as described [31,45] and cell growth was inhibited (Fig. 1). Functional studies indicated that U937 cells were differentiated into cells with characteristic properties of the macrophage pathway.

\subsection{Western blot detection of proteasomes (prosomes) in un-induced and induced cells}

Total proteins extracted from 250,000 non-induced control cells were separated by SDS-PAGE, transferred on nitrocellulose membrane and detected by antibodies. The specific monoclonal antibodies against p25K, p27K and p30/33K gave clear, single bands on western blots (Fig. 2).

In $72 \mathrm{~h}$ RA+VD-induced cells, the three subunits were decreased, especially the p27K. In contrast, no decrease was observed in PMA-induced cells, and even p25K seemed slightly increased. It should be noted that with a constant number of cells used for the extraction of proteins, the Coomassie staining (lanes a) showed an overloading of proteins in PMA-induced cells compared to control and $\mathrm{RA}+\mathrm{VD}$-induced cells. This might be due to the increase in cell size observed after PMA treatment. 


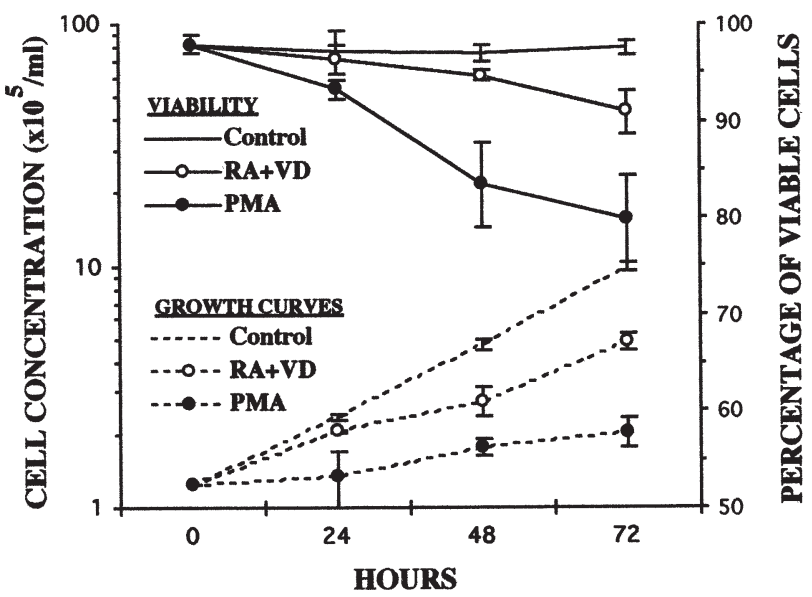

Fig. 1. Growth and viability of control and induced cells. Cells were rinsed and seeded at initial concentration of $1.25 \times 10^{5} / \mathrm{ml}$ with the different inducers. Cell concentration (dashed lines, left logarithmic ordinate) and percentage of viable cells (solid lines, right ordinate) were followed during three days.

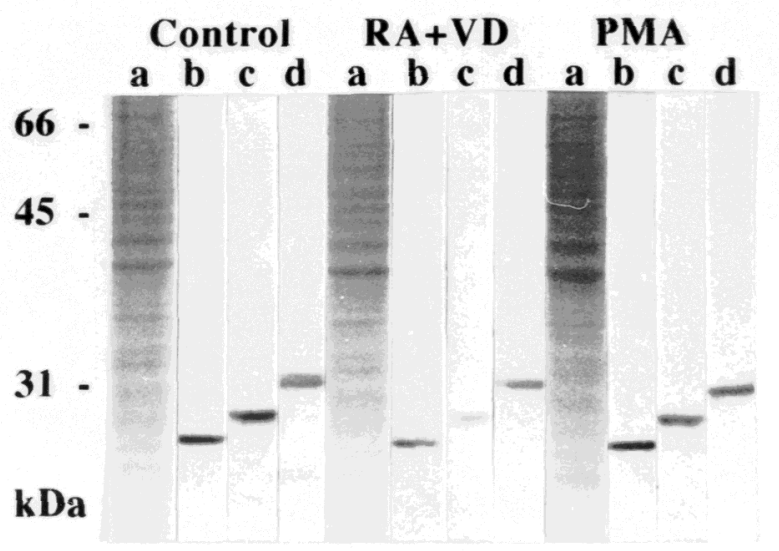

Fig. 2. Western blot detection of proteasomal proteins of control cells and cells induced to differentiate during $72 \mathrm{~h}$ by $100 \mathrm{nM}$ RA + $100 \mathrm{nM}$ VD or $160 \mathrm{nM}$ PMA. Whole protein extracts were prepared from an equal number of cells $(250,000)$ and separated by SDS-PAGE (lanes a), blotted onto nitrocellulose and analyzed with the p-mAbs anti-p25K (lanes b), anti-p27K (lanes c) and anti-p30/33K (lanes d). Anti-p25K (7A11) recognize a protein of $25 \mathrm{kDa}$ which was identified as the $\mathrm{C} 3$ alpha subunit, anti-p27K (IB5) react with a $27 \mathrm{kDa}$ protein identified as the IOTA alpha subunit and anti-p30/33K (62A32) recognize a $33 \mathrm{kDa}$ protein known as the $\mathrm{C} 2$ alpha subunit. Irrelevant was included in each series using normal mouse immunoglobulins in place of the monoclonal antibody.

\subsection{Flow cytometric detection of proteasomal proteins during differentiation}

Flow cytometry was used to follow the $20 \mathrm{~S}$ proteasome changes during differentiation (Fig. 3). Cellular proteasomes were monitored by flow cytometry after permeation of cells by ethanol [29] allowing penetration of the p-mAbs. Results are expressed as mean fluorescence intensity (MFI) \pm standard error of the mean (SEM) of 10,000 cells for at least three different experiments, and not as percentage of positive cells, since the cells behaved as an homogeneous population. Mouse total immunoglobulins were used as irrelevant antibodies. The variations in MFI of the irrelevant antibody 

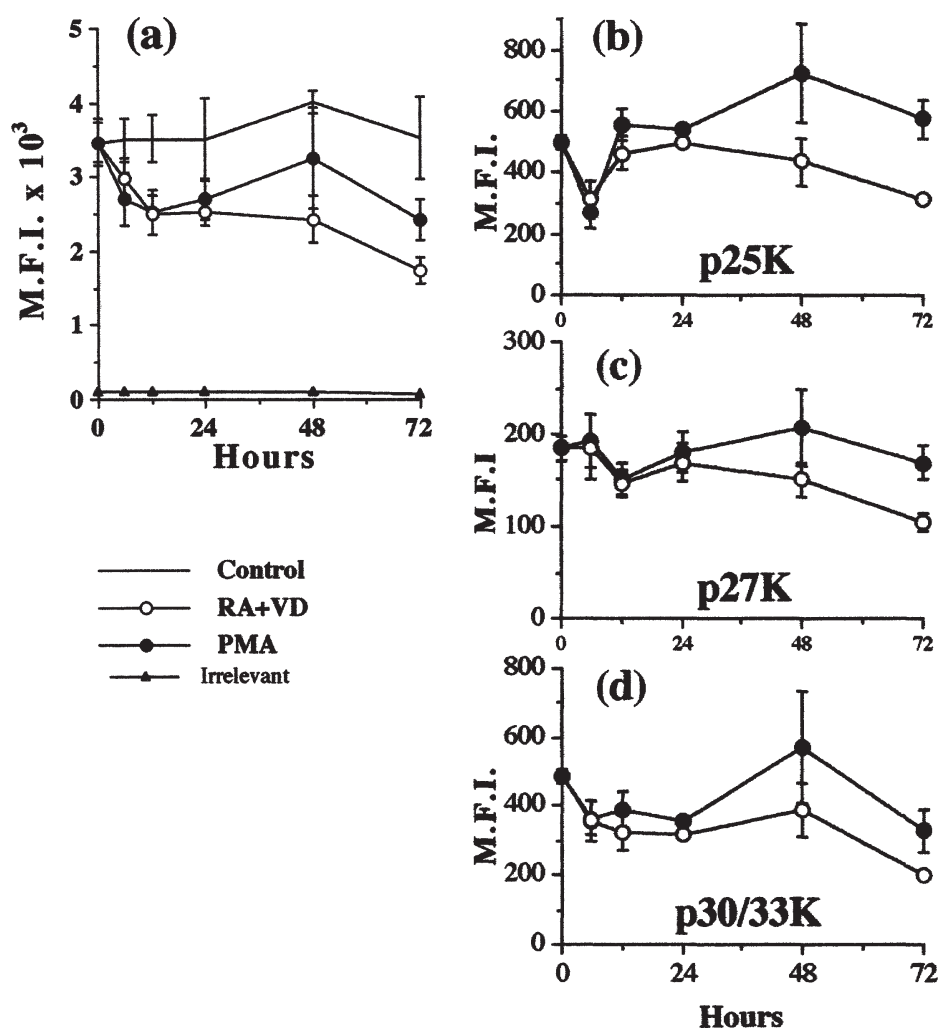

Fig. 3. (a) Flow cytometric detection of proteasomal proteins on control and induced U937 cells. For each time-point, the cells were permeated by incubation for $30 \mathrm{~min}$ in cold $70 \%$ ethanol and incubated with a panel of 7 monoclonal antibodies. GAM-FITC was used as conjugated secondary antibody. MFI of 10,000 cells was determined by flow cytometry (FACScan, Becton-Dickinson, Mountain View, USA). Each point on the curves is the mean MFI \pm SEM of at least three different experiments. Non-specific immunoreaction was low (MFI of $90.47 \pm 3.22$, data not shown), as determined with irrelevant total mouse immunoglobulins. Flow cytometric detection by monoclonal antibodies anti-p25K (b), anti-p27K (c) and anti-p30/33K (d) of proteasomal protein subunits on RA+VD and PMA-induced U937 cells. The proteasomal protein subunit contents of non-induced control cells remained constant throughout the $72 \mathrm{~h}$ period of experiment (see $T=0$ ).

from one experiment to another, and in treated or untreated-cells, were low and not significant (MFI of $90.47 \pm 3.22$ ). The amount of cellular $20 \mathrm{~S}$ proteasomes in control cells, detected with a mixture of seven anti-proteasome monoclonal antibodies (recognizing various proteins of 21, 23, 25, 27, 29, 31 and $33 \mathrm{kDa}$ ), was constant throughout the $72 \mathrm{~h}$ period of the experiments (Fig. 3(a)). PMA and $\mathrm{RA}+\mathrm{VD}$ both induced changes with a similar general trend. First, there was a rapid (as early as $6 \mathrm{~h}$ after induction) and large decrease in the proteasomes detection; thereafter, the labeling remained low or increased occasionally and finally, after two days of differentiation, the amount of the proteasomes detected decreased further. Interestingly, from 24 to $48 \mathrm{~h}$, the proteasome detection in PMA-induced cells seemed to increase transiently, whereas in RA+VD-induced cells, the decrease continued.

In view of the known compositional variability of the $20 \mathrm{~S}$ proteasome complex $[2,10,36,42]$, the changes in individual subunits during differentiation were monitored with monoclonal antibodies. The apparent amounts of individual proteasomal proteins detected in non-induced control cells were quite different: a MFI of $506.41 \pm 29.33$ was found for the $\mathrm{p} 25 \mathrm{~K}$ antigen, $184.32 \pm 13.84$ for $\mathrm{p} 27 \mathrm{~K}$ and $489.00 \pm 20.74$ for p30/33K (Fig. 3(b)-(d), $T=0$ ) and did not vary in control cells during the experiment time. With the various inducer used, the general trend of the changes in the three 


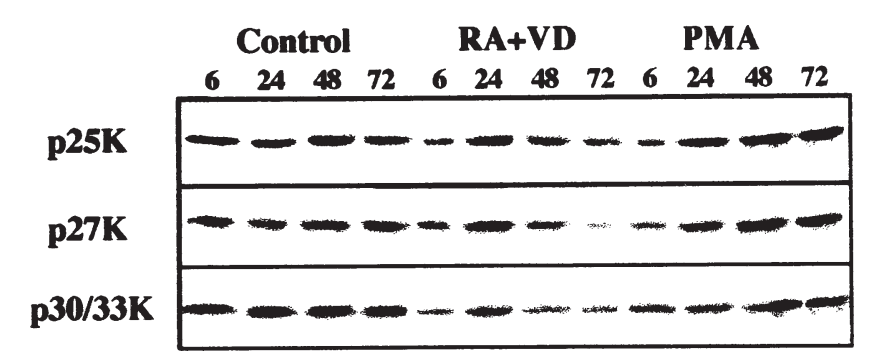

Fig. 4. Western blot detection of proteasomal protein subunits in whole cell extracts during the $72 \mathrm{~h}$ period of differentiation induced by $\mathrm{RA}+\mathrm{VD}$ or PMA.

proteasomal proteins during differentiation were similar. There was a rapid initial decrease followed by a transient increase and then a second decrease at three days of differentiation. In PMA-induced cells, the proteasomal antigens rapidly decreased, at $6 \mathrm{~h}$ for $\mathrm{p} 25 \mathrm{~K}$ and $\mathrm{p} 30 / 33 \mathrm{~K}$ (MFI of $268.05 \pm 6.86$ and $365.00 \pm 48.21$, respectively) and $12 \mathrm{~h}$ for $\mathrm{p} 27 \mathrm{~K}$ (MFI of $150.75 \pm 17.79$ ). Thereafter, the amount of these proteins increased to reach a maximum at $48 \mathrm{~h}$, they were then higher than the control level (MFI of $724.01 \pm 86.69$ for $\mathrm{p} 25 \mathrm{~K}, 207.00 \pm 40.80$ for $\mathrm{p} 27 \mathrm{~K}$ and $571.67 \pm 161.28$ for p30/33K). Finally, all proteins tested decreased between 48 and $72 \mathrm{~h}$ to reach nearly control levels $(T=0)$ except for the $\mathrm{p} 30 / 33 \mathrm{~K}$ subunit which decreased further.

Until $24 \mathrm{~h}$, the changes in the level of proteasomal proteins of RA+VD-induced cells were similar to those of PMA induced cells. Thereafter, there was less labeled protein in RA+VD-induced than in PMA-induced cells. In fact, proteasomal proteins did not increase between 24 and $48 \mathrm{~h}$, but began to decrease to final levels, except for p30/33K which increased slightly at $48 \mathrm{~h}$. Finally, all three subunits decreased between 48 and $72 \mathrm{~h}$, but attained levels clearly below than those found in non-induced cells, in contrast to PMA-induced cells.

\subsection{Western blot detection of proteasomal proteins during differentiation}

The kinetic of proteasomal antigens changes during differentiation were confirmed by western blotting (Fig. 4). The amount of subunits were decreased after $6 \mathrm{~h}$ of induction in both differentiated cells, they were also decreased at the end of RA+VD-induced differentiation. Figure 4 confirms that proteasomal subunits were not decreased at the end of PMA-induced cells.

\subsection{Flow cytometry study of changes in proteasome protein level in relation to the cell cycle}

Double staining of proteasome and DNA was carried out to follow the proteasome protein content during the cell cycle. In G2/M phase of non-induced control cells, more p25K, p27K and p30/33K proteasomes were detected than in S-phase cells which, in turn contained more than the G0/G1 phase cells. The p25K, p27K and p30/33K subunit content was linearly correlated with the DNA content (correlation coefficient $r^{2}>0.99$ ). These differences in the relative detection of proteasomal antigens in the phases of the cell cycle were conserved during differentiation, indicating that the changes in protein content were the same in the three phases of the cycle (correlation coefficient $r^{2}>0.96$, data not shown). Figure 5 shows the example of variations in subunit $\mathrm{p} 30 / 33 \mathrm{~K}$ at $72 \mathrm{~h}$ of incubation. These results confirmed our previous works [19], meaning that differentiation induced general changes in proteasome content without modification in the relative amount encountered in the different phases of the cell cycle. 


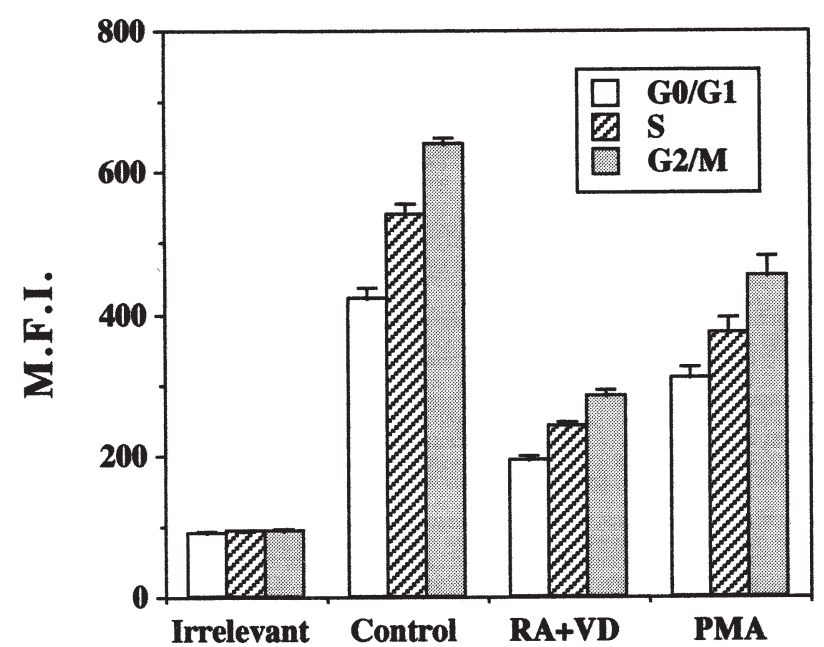

Fig. 5. Flow cytometric detection of proteasomal subunit p30/33K in the different phases of the cell cycle of non-induced and $72 \mathrm{~h} \mathrm{RA}+\mathrm{VD}$ and PMA-induced cells. The subunits detection is linearly correlated with the DNA content.

\subsection{Localization of proteasomes by immunofluorescence microscopy}

Proteasomal subunits were detected by immunofluorescence microscopy using monoclonal antibodies on permeated U937 cells. The subunits $\mathrm{p} 25 \mathrm{~K}, \mathrm{p} 27 \mathrm{~K}$ and $\mathrm{p} 30 / 33 \mathrm{~K}$ were highly labeled in non-induced control cells (Fig. 6A, D and G), whereas the non-specific fluorescence of cells incubated with the fluorochrome conjugated secondary antibody alone was very low (data not shown). The three antigens were detected in the nucleus as well as in the cytoplasm, showing a regular and diffuse distribution, but the fluorescence intensity was higher in the cytoplasm. In addition, for p27K, some more intensively labeled areas were observed around the nucleus (Fig. 6D).

Differentiated cells were examined after $72 \mathrm{~h}$. Staining of all three proteasomal proteins was strongly decreased in the nucleus and, to a lesser extent, in the cytoplasm of RA+VD-induced cells (Fig. 6B, $\mathrm{E}$ and $\mathrm{H}$ ), with an apparent loss of the nuclear p27K antigen (Fig. 6E). The decrease in cytoplasmic $\mathrm{p} 30 / 33 \mathrm{~K}$ antigen was less pronounced than those of $\mathrm{p} 25 \mathrm{~K}$ and $\mathrm{p} 27 \mathrm{~K}$ subunits. The distribution of proteasomal antigens was regular and appeared more often in a granular pattern.

The amounts of proteasomal antigens detected in PMA-induced cells (Fig. 6C, F and I) seemed to decrease. Antigen $\mathrm{p} 25 \mathrm{~K}$ was reduced in both compartments; in some cells having adopted a highly differentiated phenotype, reduction was particularly strong (Fig. 6C). Although p27K and p30/33K staining was reduced in the cytoplasm (Fig. $6 \mathrm{~F}$ and I), there was no decrease in the nucleus, but the fluorescence appeared in heterogeneous "patchy" pattern, suggesting a reorganization of proteasomes in the nucleus. Cyto-immunofluorescence seemed to show a decrease in proteasomal antigens but they were rather scattered in the cytoplasm, since PMA-induced cells were larger than control cells. Thus, the global content of antigens per cell was unchanged as determined by western blotting.

\subsection{Western blot detection of intracellular proteasomal antigens from different subcellular fractions}

The immunofluorescence data were further confirmed by western blotting analysis of fractionated protein extracts. The gel (Fig. 7) was voluntarily overloaded, compared to Figs 2 and 4, to allow nucleus antigens to become apparent. Proteasomal subunits were detected in whole cell extracts 

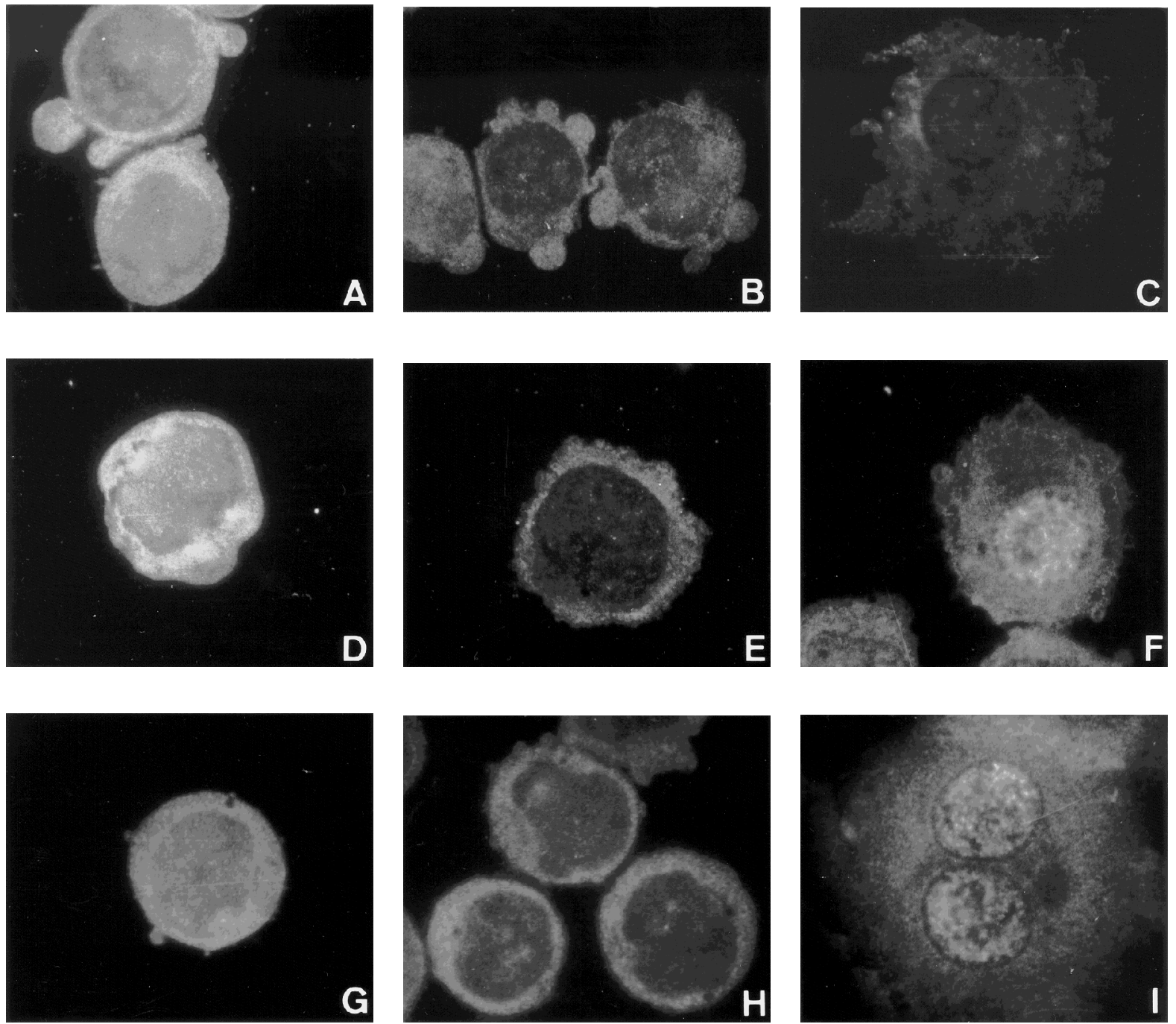

Fig. 6. Detection by cyto-immunofluorescence of proteasomal subunits p25K (A, B, C), p27K (D, E, F) and p30/33K $(\mathrm{G}, \mathrm{H}, \mathrm{I})$, in control cells (A, D, G), and cells incubated for $72 \mathrm{~h}$ with RA+VD (B, E, H) or PMA (C, F, I). Cells were cyto-centrifuged, fixed and permeated by incubation for $15 \mathrm{~min}$ in $0.5 \%$ Tween-20 in PBS; proteasomal antigens were then detected with p-mAbs. Magnification $2000 \times, 1 \mathrm{~cm}=5 \mu \mathrm{m}$.

(lanes a), in the nuclear pellet (lanes c), and in the post-mitochondrial supernatant (lanes b) devoid of mitochondria, vacuoles, lysozymes and membrane fragments. Considering the whole population of control cells in which the percentage of cells in the different cell cycle phases was constant, the level of detection remained constant in both fractions during the time of experimentation (Fig. 7).

$\mathrm{p} 25 \mathrm{~K}, \mathrm{p} 27 \mathrm{~K}$ and $\mathrm{p} 30 / 33 \mathrm{~K}$ antigens were all markedly decreased in the nuclear pellet of RA+VDinduced cells. In PMA-induced cells, only p25K antigen was decreased, whereas p30/33K antigens seemed unchanged and $\mathrm{p} 27 \mathrm{~K}$ was slightly increased.

The amounts of proteasomal proteins in the post-mitochondrial supernatant were decreased in cells induced with RA+VD for $72 \mathrm{~h}$ (Fig. 7), while they seemed unchanged in PMA-induced cells. 


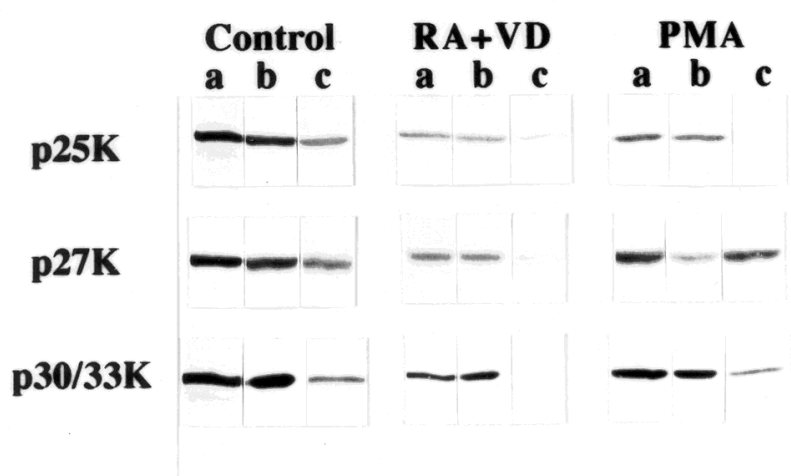

Fig. 7. Western blot detection of proteasomal proteins in whole cell extracts (lanes a), post-mitochondrial supernatant (lanes b) and nuclear pellet (lanes c) isolated from control and induced U937 cells. Cells were incubated $72 \mathrm{~h}$ with inducers and fractionated, the proteins separated by SDS-PAGE, blotted on NC and analyzed with the monoclonal antibodies. In this case, the gel was voluntarily overloaded to allow nucleus antigens to become apparent.

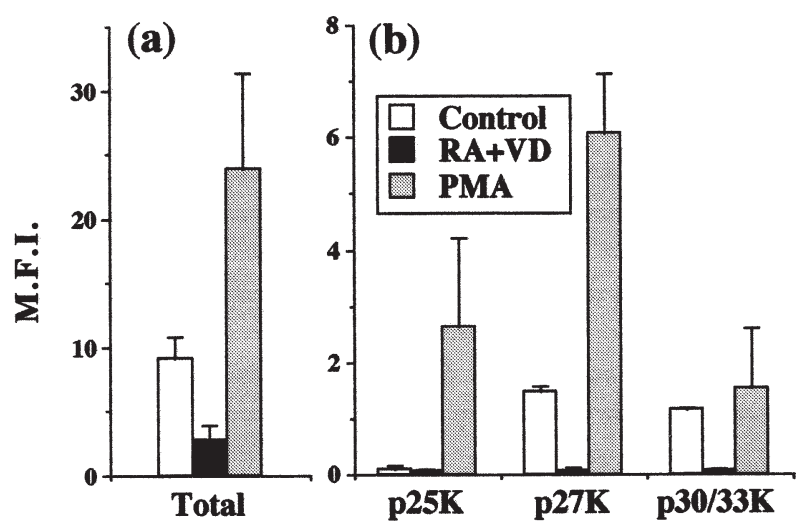

Fig. 8. Flow cytometric detection of proteasomal subunits on the plasma membrane of control and $72 \mathrm{~h}$ induced U937 cells. Cells were carefully washed to avoid non-specific binding. (a) Main plasma membrane antigens detected with a panel of 7 monoclonal antibodies. (b) Various proteasomal protein subunits detected with monoclonal antibodies.

\subsection{Flow cytometric detection of proteasomal antigens on the cell surface}

Since proteasomal proteins had been detected on erythrocyte and blood cell membranes $[9,22,24]$, we checked if they might be present at the surface of U937 cells and whether there were any changes in surface antigens during differentiation. To this extent, we analyzed proteasome proteins on cells which were not permeated prior to immunoreaction (Fig. 8) and which were drastically washed to avoid non-specific binding of extracellular proteins. Specific labeling of surface proteasome proteins was low in general, compared to their intracellular level. A specific binding of immunoglobulins, determined by using an irrelevant antibody, differed between control $(4.10 \pm 0.62)$ and differentiated cells $(5.97 \pm 0.94$ for RA+VD-induced versus $10.78 \pm 1.19$ for PMA-induced cells). Therefore, the MFI data were expressed after subtraction of irrelevant MFI (Fig. 8).

Using a mixture of antibodies, proteasome antigens labeling on non-induced control cell membranes was low (MFI of $9.15 \pm 1.63$, Fig. 8(a)). On RA+VD-induced cells membrane, proteasomal proteins 
became hardly detectable (MFI of $2.77 \pm 1.12$ ). In contrast, proteasome antigens detection on PMAinduced cells membrane was strongly increased (MFI of $23.95 \pm 7.42$ ).

Considering proteasomal subunits (Fig. 8(b)), all proteins tested were weakly labeled at the surface of control cells, p25K antigen seemed absent, p27K $(1.48 \pm 0.27)$ and p30/33K $(1.15 \pm 0.46)$ antigens were slightly detected. After three days of differentiation, the membrane proteins tested were markedly decreased on RA+VD-induced cells. In contrast on PMA-induced cells, while the p30/33K antigen was unchanged, the p25K and p $27 \mathrm{~K}$ antigens had clearly increased.

\section{Discussion}

This study is based on the finding that the subunit composition of proteasomes (prosomes) and their cytodistribution varies with physiological and pathological changes, and with cell differentiation and embryonic development (reviewed in [42]). These observations are in line with the finding that interferon treatment of HeLa cells, the LMP2, LMP7 and MECL1 subunits replace the corresponding $\mathrm{X}, \mathrm{Y}$ and $\mathrm{Z}$ proteins of the untreated cells within hours [2,33]. Particularly relevant to the present study, is also the finding that the composition of the $20 \mathrm{~S}$ complex varies with the intracellular location in rat liver cells [37]. Proteasomes were also demonstrated to be over-expressed in a variety of tumour and tumour cell lines $[7,21,27]$. All these data have led to the suggestion that proteasomes may be used as tumour markers $[7,8,42]$

We have therefore monitored the changes in protein subunits during the stimulation of the histiocytic leukemia U937 cell line to obtain further information on the role of proteasomes and their variability in differentiation and malignancy. The data obtained by western blotting, flow cytometry and cyto-immunofluorescence, all showed that there was an overall decrease in proteasomes detection in $\mathrm{RA}+\mathrm{VD}$-induced cells. In contrast in PMA-induced cells, whereas cyto-immunofluorescence showed an apparent decrease in proteasomal proteins at $72 \mathrm{~h}$, this was not observed by flow cytometry and western blotting, as they indicated that the apparent content of the subunits monitored was not significantly different from that of non-induced control cells. This difference might be due to the difference in cell size [31] and then the scattering of antigens in PMA-induced cells.

Flow cytometry (Fig. 3) showed that there was a rapid initial decrease in proteasomal proteins detection, followed by a stable period in RA+VD-induced cells and a transient increase in PMAinduced cells. But the detection of antigens decreased in both type of differentiated cells after $48 \mathrm{~h}$. Most of the proteasomal subunit proteins studied indicate the same trend [19].

The decrease in proteasomal subunits detection was not due to masking of $20 \mathrm{~S}$ epitopes since the MFI data were confirmed by protein analysis using western blotting. The apparent changes observed could rather be explained by timely adjustments in the proteasome types needed for protein synthesis and breakdown during reprogramming of the cell and differentiation. In this issue, the hypothesis of Coux et al. [11] that "the production of new proteasomes may be regulated at the translational level or during particle assembly, and that the excess subunits not incorporated may be rapidly degraded" is particularly relevant and explains the discrepancy between the rapid changes observed and the known long half-life of proteasomes [46].

Another possible explanation of the changes in subunits detection could be the disturbance of antigen-antibody reactivity by post-translational modifications. The three subunits tested share a phosphorylation site and it has been demonstrated that monoclonal antibody do not always recognize different isoforms of a given subunit with the same affinity [30]. Thus, the changes observed could be the hallmark of the regulation between phosphorylated and unphosphorylated forms of the subunits. 
The data reported here (Figs 6 and 7) indicated a particular decrease in antigens in the nucleus in $\mathrm{RA}+\mathrm{VD}$-induced cells, and rather a scattering in the cytoplasm and a reorganization in the nucleus in PMA-induced cells. These differences are not totally unexpected, since the final phenotype of the cells induced to differentiate is not identical and the inducers used act by quite different pathways (i.e., cytosolic receptors for PMA [4] and nuclear receptors for RA and VD [28,39]). This is in line with a subtle and differential modulation in the specific functions of proteasomes in the nucleus and cytoplasm, rather than a more general phenomena, such as the cell cycle or DNA replication. While the apparent decrease in p25K (C3) in the nucleus of both differentiated cells could be related to cell growth inhibition, this is not the case for p27K (IOTA) and p30/33K (C2). These proteins certainly have functions other than regulating the cell cycle, since their contents are not correlated with the changes in the cell cycle. Hence, alternative types of proteasomes may be necessary, with the changes in gene expression that occur during differentiation induced by various compounds.

The confirmation that there were proteasomal antigens at the cell surface is particularly interesting (Fig. 8). The proteasomal antigens $\mathrm{p} 27 \mathrm{~K}$ and $\mathrm{p} 30 / 33 \mathrm{~K}$, faintly detected at the surface of non-induced control cells, disappeared from RA+VD-induced cells. At the surface of PMA-induced cells, p25K and $\mathrm{p} 27 \mathrm{~K}$ were strongly increased while $\mathrm{p} 30 / 33 \mathrm{~K}$ was unchanged compared to control cells. These surface antigens were not due to the non-specific binding of extracellular antigens, since cells were thoroughly washed before flow cytometry, and since the proteasome antigens were detected even after trypsinisation [9]. The changes in the proteasomal proteins detected during differentiation indicated that these specific subunits were somehow linked to the expression of the specialized function of the myeloid cells. The recent identification of a membrane-bound inhibitor of MCP [23] suggests that there is a localized, specific regulation of proteasome activity at the membrane level, further indicating that membranal proteasomes have a specific function. Since the plasma membrane subunit patterns in the induced and in the control cells differed from that of the intracellular proteasomes, the surface antigens seemed to be genuine. Further studies are needed to know whether proteasomes or only proteasomal proteins are present at the cell surface; particularly, it is of interest to determine the kind of relationship between proteasome particles (or proteins) and the major histocompatibility complex (MHC) molecules involved in the antigen presentation at the cell surface.

From this study, it appeared that the presence of proteasomes in the cell was not a sufficient criteria for tumour diagnosis. This is in line with the description of high content of proteasomes in nontumoural rapidly dividing cells. It is more that the proteasome (prosome) population of myeloid cells adapts to induced differentiation by subtle changes in subunit profiles of intracellular and cell surface proteins at translational or/and post-translational level. The complexity of the proteasome system precludes any simple general explanation. Only further detailed multiparametric studies will lead to an understanding of their different putative function.

\section{Acknowledgements}

This work was supported by the Ministère de l'Environnement, the Ligue Nationale Contre le Cancer (Comités de l'Aude et du Gard) and the Fondation pour la Recherche Médicale. We are grateful to Dr. K.B. Hendil for personal communications, Hoffmann-LaRoche SA (Basel, Switzerland) for providing VD and R. Hunzinger for technical assistance. 


\section{References}

[1] J.Y. Ahn, S.O. Hong, K.B. Kwak, S.S. Kang, K. Tanaka, A. Ichihara, D.B. Ha and C.H. Chung, Developmental regulation of proteolytic activities and subunit pattern of $20 \mathrm{~S}$ proteasome in chick embryonic muscle, J. Biol. Chem. 266 (1991), $15746-15749$.

[2] K. Akiyama, S. Kagawa, T. Tamura, N. Shimbara, M. Takashina, P. Kristensen, K.B. Hendil, K. Tanaka and A. Ichihara, Replacement of proteasome subunits X and Y by LMP7 and LMP2 induced by interferon-gamma for acquirement of the functional diversity responsible for antigen processing, FEBS Lett. 343 (1994), 85-88.

[3] A.P. Arrigo, K. Tanaka, A.L. Goldberg and W.J. Welch, Identity of the 19S 'prosome' particle with the large multifunctional protease complex of mammalian cells (the proteasome), Nature 331 (1988), 192-194.

[4] C.L. Ashendel, The phorbol ester receptor: a phospholipid-regulated protein kinase, Biochim. Biophys. Acta 822 (1985), 219-242.

[5] A. Baz, L. Henry, R. Caravano, K. Scherrer and J.P. Bureau, Changes in the subunit distribution of prosomes (MCPproteasomes) during the differentiation of human leukemic cells, Int. J. Cancer 72 (1997), 467-476.

[6] M.P. Belich and J. Trowsdale, Proteasome and class I antigen processing and presentation, Mol. Biol. Rep. 21 (1995), 53-56.

[7] A.J. Bhui, J.P. Bureau, A. Abbas, A. Mondal, K. Scherrer, A. Kurkure and A. Therwath, Novel cellular markers in breast cancer: differential presence of $\mathrm{p} 23 \mathrm{~K}$ and p30/33K prosomal antigens in tumours of Parsi and non-Parsi women, Int. J. Oncol. 9 (1996), 669-677.

[8] A.J. Bhui, A. Therwath, V.A. Parikh, M.R. Simha, M. Olink-Coux, A. Kurkure, V.M. Doctor, K. Scherrer and J.-P. Bureau, Breast carcinoma in a high-risk population: modified expression of $25 \mathrm{~K}$ and $31 \mathrm{~K}$ prosome antigens, Breast Diseases 7 (1994), 109-127.

[9] J.P. Bureau, M. Olink-Coux, N. Brouard, S. Baile-Julien, M. Huesca, M. Herzberg and K. Scherrer, Characterization of prosomes in human lymphocyte subpopulations and their presence as surface antigens, Exp. Cell Res. 231 (1997), $50-60$.

[10] C. Cardozo, A.M. Eleuteri and M. Orlowski, Differences in catalytic activities and subunit pattern of multicatalytic proteinase complexes (proteasomes) isolated from bovine pituitary, lung, and liver. Changes in LMP7 and the component necessary for expression of the chymotrypsin-like activity, J. Biol. Chem. 270 (1995), 22 645-22 651.

[11] O. Coux, K. Tanaka and A.L. Goldberg, Structure and functions of the 20S and 26S proteasomes, Ann. Rev. Biochem. 65 (1996), 801-847.

[12] B. Dahlmann, F. Kopp, L. Kuehn, B. Niedel, G. Pfeifer, R. Hegerl and W. Baumeister, The multicatalytic proteinase (prosome) is ubiquitous from eukaryotes to archaebacteria, FEBS Lett. 251 (1989), 125-131.

[13] S.P. Dawson, J.E. Arnold, N.J. Mayer, S.E. Reynolds, M.A. Billett, C. Gordon, L. Colleaux, P.M. Kloetzel, K. Tanaka and R.J. Mayer, Developmental changes of the 26S proteasome in abdominal intersegmental muscles of Manduca sexta during programmed cell death, J. Biol. Chem. 270 (1995), 1850-1858.

[14] C. Ebisui, T. Tsujinaka, T. Morimoto, J. Fujita, A. Ogawa, K. Ishidoh, E. Kominami, K. Tanaka and M. Monden, Changes of proteasomes and cathepsins activities and their expression during differentiation of $\mathrm{C} 2 \mathrm{C} 12$ myoblasts, J. Biochem. 117 (1995), 1088-1094.

[15] E. Eytan, D. Ganoth, T. Armon and A. Hershko, ATP-dependent incorporation of 20S protease into the 26S complex that degrades proteins conjugated to ubiquitin, Proc. Natl. Acad. Sci. USA 86 (1989), 7751-7755.

[16] M. Groll, L. Ditzel, J. Löwe, D. Stock, M. Bochtler, H.D. Bartunik and R. Huber, Structure of 20 S proteasome from yeast at 2.4A resolution, Nature 386 (1997), 463-471.

[17] M.F. Grossi de Sa, C. Martins de Sa, F. Harper, O. Coux, O. Akhayat, J.K. Pal, Y. Florentin and K. Scherrer, Cytolocalization of prosomes as a function of differentiation, J. Cell Sci. 89 (1988), 151-165.

[18] C. Haass and P.M. Kloetzel, The Drosophila proteasome undergoes changes in its subunit pattern during development, Exp. Cell Res. 180 (1989), 243-252.

[19] L. Henry, A. Baz, M.T. Château, K. Scherrer and J.P. Bureau, Changes in the amount and distribution of prosomal subunits during the differentiation of U937 myeloid cells: high expression of p23K, Cell Prolif. 29 (1996), 589-607.

[20] A. Ichihara and K. Tanaka, Roles of proteasomes in cell growth, Mol. Biol. Rep. 21 (1995), 49-52.

[21] H. Kanayama, K. Tanaka, M. Aki, S. Kagawa, H. Miyaji, M. Satoh, F. Okada, S. Sato, N. Shimbara and A. Ichihara, Changes in expressions of proteasome and ubiquitin genes in human renal cancer cells, Cancer Res. 51 (1991), $6677-6685$.

[22] M.T. Khan, K. Wang, M.E. Auland, E.P. Kable and B.D. Roufogalis, Membrane-bound high molecular mass proteinases from human erythrocytes, Biochim. Biophys. Acta 1209 (1994), 215-221.

[23] M.T. Khan, K. Wang and B.D. Roufogalis, Identification and purification of a $90 \mathrm{kDa}$ membrane-bound endogenous inhibitor of multicatalytic proteinase from human erythrocytes, Biochem. Biophys. Res. Comm. 214 (1995), 957-962.

[24] M. Kinoshita, T. Hamakubo, I. Fukui, T. Murachi and H. Toyohara, Significant amount of multicatalytic proteinase identified on membrane from human erythrocyte, J. Biochem. 107 (1990), 440-444. 
[25] F. Kopp, K.B. Hendil, B. Dahlmann, P. Kristensen, A. Sobek and W. Uerkwitz, Subunit arrangement in the human 20S proteasome, Proc. Natl. Acad. Sci. USA 94 (1997), 2939-2944.

[26] P. Kristensen, A.H. Johnsen, W. Uerkvitz, K. Tanaka and K.B. Hendil, Human proteasome subunits from 2-dimensional gels identified by partial sequencing, Biochem. Biophys. Res. Comm. 205 (1994), 1785-1789 (published erratum appears in Biochem. Biophys. Res. Comm. 207(3) (1995), 1059).

[27] A. Kumatori, K. Tanaka, N. Inamura, S. Sone, T. Ogura, T. Matsumoto, T. Tachikawa, S. Shin and A. Ichihara, Abnormally high expression of proteasomes in human leukemic cells, Proc. Natl. Acad. Sci. USA 87 (1990), 70717075 .

[28] R. Lotan and J.L. Clifford, Nuclear receptors for retinoids: mediators of retinoid effects on normal and malignant cells, Biomed. Pharmacother. 45 (1991), 145-156.

[29] B.M. Machiels, M.E. Henfling, J.L. Broers, K.B. Hendil and F.C. Ramekers, Changes in immunocytochemical detectability of proteasome epitopes depending on cell growth and fixation conditions of lung cancer cell lines, Eur. J. Cell Biol. 66 (1995), 282-292.

[30] G.G. Mason, K.B. Hendil and A.J. Rivett, Phosphorylation of proteasomes in mammalian cells. Identification of two phosphorylated subunits and the effect of phosphorylation on activity, Eur. J. Biochem. 238 (1996), 453-462.

[31] J.O. Minta and L. Pambrun, In vitro induction of cytologic and functional differentiation of the immature human monocytelike cell line U-937 with phorbol myristate acetate, Am. J. Pathol. 119 (1985), 111-126.

[32] J.J. Monaco, Pathways for the processing and presentation of antigens to T cells, J. Leuk. Biol. 57 (1995), $543-547$.

[33] D. Nandi, H. Jiang and J.J. Monaco, Identification of MECL-1 (LMP-10) as the third IFN-gamma-inducible proteasome subunit, J. Immunol. 156 (1996), 2361-2364.

[34] A. Orian, S. Whiteside, A. Israel, I. Stancovski, A.L. Schwartz and A. Ciechanover, Ubiquitin-mediated processing of NF-kappa B transcriptional activator precursor p105. Reconstitution of a cell-free system and identification of the ubiquitin-carrier protein, E2, and a novel ubiquitin-protein ligase, E3, involved in conjugation, J. Biol. Chem. 270 (1995), $21707-21714$.

[35] H.L. Pahl and P.A. Baeuerle, Control of gene expression by proteolysis, Curr. Opin. Cell Biol. 8 (1996), $340-347$.

[36] J.K. Pal, P. Gounon, M.F. Grossi de Sa and K. Scherrer, Presence and distribution of specific prosome antigens change as a function of embryonic development and tissue-type differentiation in Pleurodeles waltl, J. Cell Sci. 90 (1988), 555-567.

[37] A. Palmer, A.J. Rivett, S. Thomson, K.B. Hendil, G.W. Butcher, G. Fuertes and E. Knecht, Subpopulations of proteasomes in rat liver nuclei, microsomes and cytosol, Biochem. J. 316 (1996), 401-407.

[38] F. Petit, A.S. Jarrousse, B. Dahlmann, A. Sobek, K.B. Hendil, J. Buri, Y. Briand and H.P. Schmid, Involvement of protesomal subunits zeta and iota in RNA-degradation, Biochem. J. 326 (1997), 93-98.

[39] J.W. Pike, Vitamin D3 receptors: structure and function in transcription, Ann. Rev. Nutr. 11 (1991), 189-216.

[40] M.N. Pouch, F. Petit, J. Buri, Y. Briand and H.P. Schmid, Identification and initial characterization of a specific proteasome (prosome) associated RNase activity, J. Biol. Chem. 270 (1995), 22 023-22 028.

[41] B. Richter-Ruoff and D.H. Wolf, Proteasome and cell cycle. Evidence for a regulatory role of the protease on mitotic cyclins in yeast, FEBS Lett. 336 (1993), 34-36.

[42] K. Scherrer and F. Bey, The prosomes (multicatalytic proteinases; proteasomes) and their relationship to the untranslated messenger ribonucleoproteins, the cytoskeleton, and cell differentiation, Prog. Nucl. Acid Res. Mol. Biol. 49 (1994), 1-64.

[43] H.P. Schmid, O. Akhayat, C. Martins de Sa, F. Puvion, K. Koehler and K. Scherrer, The prosome: an ubiquitous morphologically distinct RNP particle associated with repressed mRNPs and containing specific ScRNA and a characteristic set of proteins, EMBO J. 3 (1984), 29-34.

[44] N. Shimbara, E. Orino, S. Sone, T. Ogura, M. Takashina, M. Shono, T. Tamura, H. Yasuda, K. Tanaka and A. Ichihara, Regulation of gene expression of proteasomes (multi-protease complexes) during growth and differentiation of human hematopoietic cells, J. Biol. Chem. 267 (1992), 18 100-18 109.

[45] M. Taimi, M.T. Chateau, S. Cabane and J. Marti, Synergistic effect of retinoic acid and 1,25-dihydroxyvitamin D3 on the differentiation of the human monocytic cell line U937, Leuk. Res. 15 (1991), 1145-1152.

[46] K. Tanaka and A. Ichihara, Half-life of proteasomes (multiprotease complexes) in rat liver, Biochem. Biophys. Res. Comm. 159 (1989), 1309-1315.

[47] K. Tanaka and C. Tsurumi, The 26S proteasome: subunits and functions, Mol. Biol. Rep. 24 (1997), 3-11.

[48] T. Tsukahara, H. Sugita and S. Ishiura, 26S multicatalytic proteinase complexes decrease during the differentiation of murine erythroleukemia cells, Biochim. Biophys. Acta 1079 (1991), 273-278.

[49] S. Wilk and M. Orlowski, Cation-sensitive neutral endopeptidase: isolation and specificity of the bovine pituitary enzyme, J. Neurochem. 35 (1980), 1172-1182. 


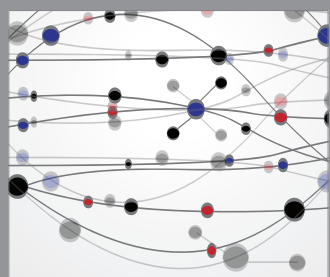

The Scientific World Journal
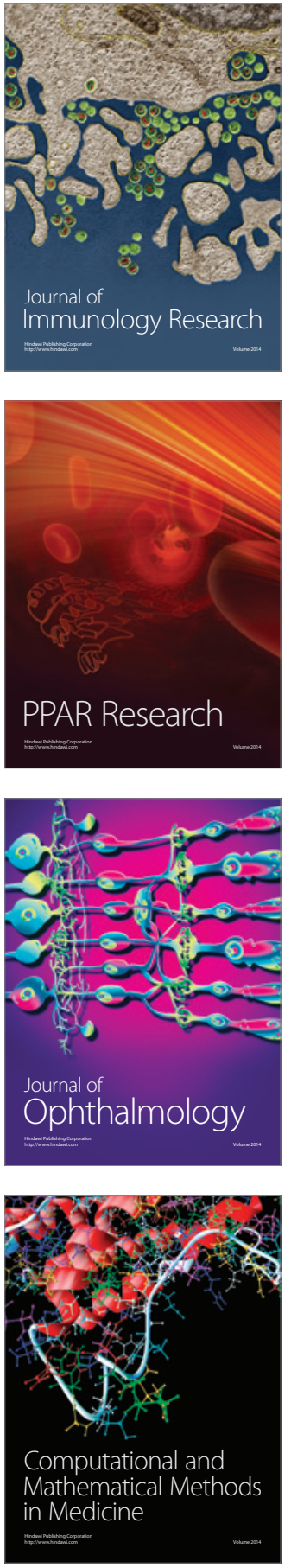

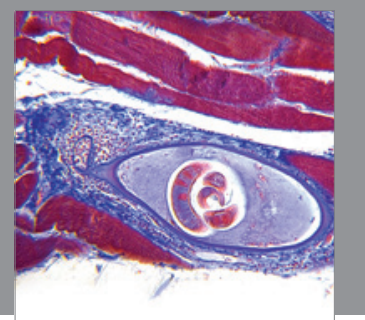

Gastroenterology

Research and Practice
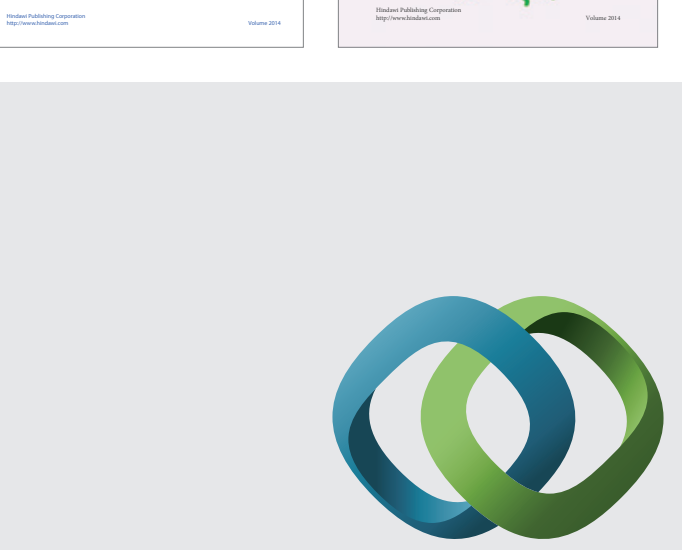

\section{Hindawi}

Submit your manuscripts at

http://www.hindawi.com
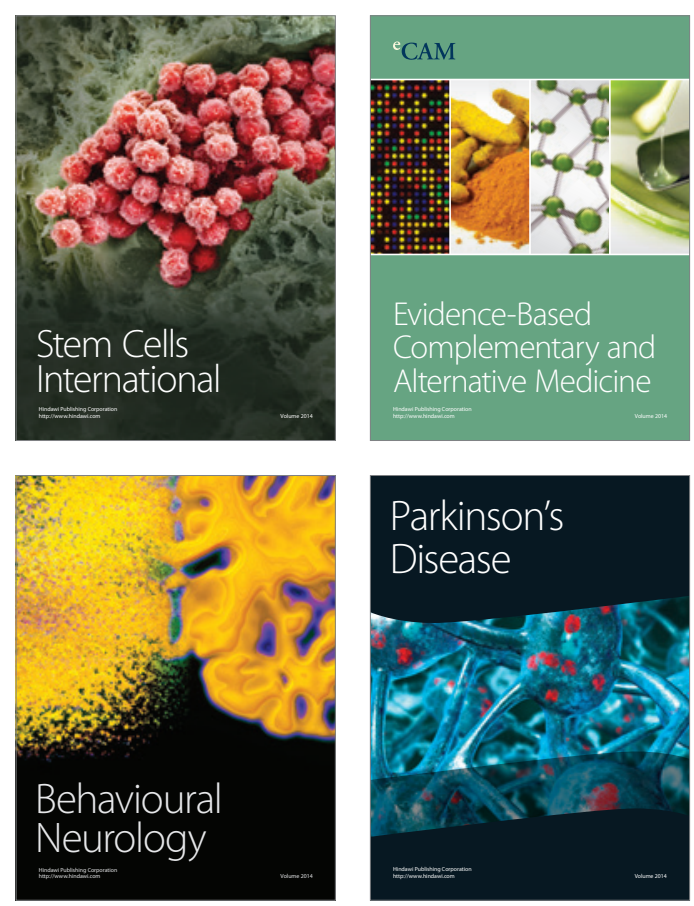

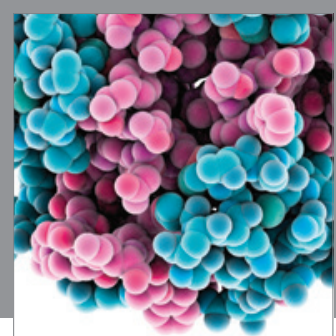

Journal of
Diabetes Research

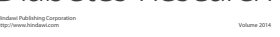

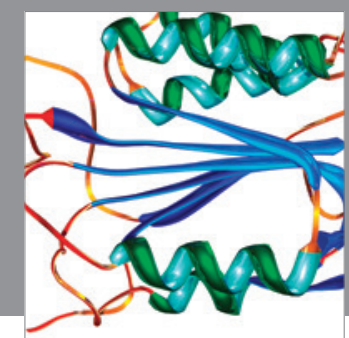

Disease Markers
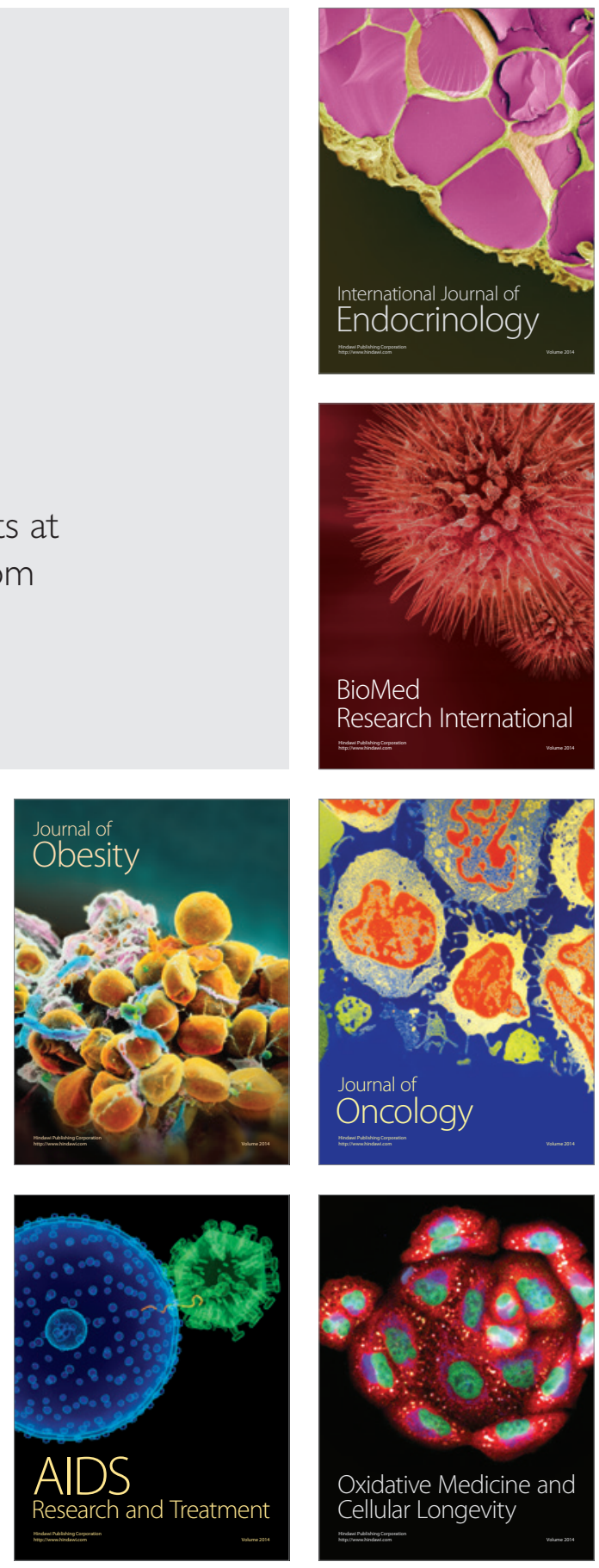